\title{
PROFITABILITY IDENTIFICATION OF NATIONAL BANKING THROUGH CREDIT, CAPITAL, CAPITAL STRUCTURE, EFFICIENCY, AND RISK
} LEVEL

\section{Sugeng Haryanto}

Finance and Banking D-III Program, Merdeka Malang University, Malang, Indonesia

Info Article

History Article:

Received September 2015

Approved October 2015

Published March 2016

Keywords:

Profitability;

Credit;

Capital Structure;

Efficiency;

Risk.

\begin{abstract}
This study aims to analyze the influence of credit, bank capital, capital structure, efficiency and risk toward the profitability in banking industry. Bank has an important role in the economy in Indonesia in 2014. The purposive sampling technique was used in this study to filter the samples according to several criteria such as being public at least in 2008, and publicly released the financial statement from 2008-2013. The total sample of 25 banks. Multiple regression technique was used in this study to analyze the data. The results show that credit, bank capital, and capital structure positively influence the profitability. This result supported by the previous research. The other finding shows that efficiency and risk have significantly negative effect on profitability. Bangking has an 80 percent market share in the financing of intermediation function of the entire financial system.
\end{abstract}

\section{IDENTIFIKASI PROFITABILITAS PERBANKAN NASIONAL MELALUI KREDIT, PERMODALAN, STRUKTUR MODAL, EFISIENSI DAN TINGKAT RISIKO}

\begin{abstract}
Abstrak
Penelitian bertujuan menganalisis pengaruh antara kredit, permodalan bank, struktur modal, efisiensi dan risiko terhadap profitabilitas pada industri perbankan. Bank mempunyai peran penting dalam ekonomi Indonesia 2014. Teknik sampling penelitian ini adalah purposive sampling, dengan kriteria bank bank telah go public sebelum tahun 2008, mempublikasikan laporan keuangan tahun 2008-2013. Jumlah sampel sebanyak 25 bank. Teknik analisis yang digunakan regresi linier berganda. Hasil penelitian menunjukkan bahwa kredit, permodalan bank dan struktur modal berpengaruh terhadap profitabilitas dengan arah positif. Hasil lainnya adalah variabel efisiensi dan risiko berpengaruh signifikan dengan arah negatif terhadap profitabilitas. Perbankan memiliki market share 80 persen dalam sistem keuangan.
\end{abstract}

JEL Classification: G3, G32 


\section{INTRODUCTION}

Bankhasanimportantrolein the economy, which is reflected in the ratio of credit to GDP in Indonesia in 2014 at around 36\% (Bank Indonesia, 2014). Banking has 80 percent market share in the financing (credit) of the intermediation function of the entire existing financial system (Astohar, 2009). Financial intermediary function arises as a result of the high cost of monitoring, the cost of liquidity and price risk because of the asymmetry of information between the owners of the fund with the fund company, so it takes intermediaries that able to accommodate the needs of both parties (Saunders and Cornett, 2008).

Bank is an industry with a high level of regulation as stipulated by Bank Indonesia. As an intermediary institution, bank funding sources are dominated by public funds, that the bank should be arranged so that depositors will be protected. Bank is an institution which is known as the risk-taking entities. Bank is an institution in which its operations are associated with risks in comparison with the manufacturing company and other companies.

Banking credit spread nationwide continued to increase, however, bank credit growth nationally in the last four years has continued to decline. Bank Indonesia data show that for the year 2012-2014, Working Capital Credit of 2011 was $21 \%$ and in 2014 to $10.8 \%$. Investment Credit in 2011 was $33.2 \%$ and in 2014 to 13.2\%. Consumption Credit in 2011 was $24.1 \%$ and in 2014 to $11.5 \%$. Some of the factors that cause the slowdown in credit growth are the external factors, where the rate of global economic growth also slowed, so the impact also on the domestic economy.

This suggests that the banking growth and development sector is closely linked to the growth and development of the real sector in which the banking industry should land the funds to deficit unit, especially the real sector, so that when the real sector weakens, it will affect the ability of banks to extend credit.
Credit holds the largest portion of bank assets. Bank as the company aims to make a profit, where the sources of bank revenue derived from: 1) interest income from loans, 2) interest income from securities, 3) Non-operating income, 4) Other interest income and 5) noninterest operating income. Income from loan interest plays a major role in maintaining the positive trend of commercial banks revenue increase in Indonesia, which in 2012 the interest income from bank credit in Indonesia reached 51.9 percent of the total income of the bank (Bank Indonesia, 2012).

Bank has the goal of how to achieve high profitability. Profitability is one indicator to assess the financial performance of the company. High profitability shows good prospects for the company, so investors will respond positively to these signals and the company's value will increase (Sudjoko \& Ugi, 2007). Profitability has important significance for the company and stakeholders since the high profitability of the company will be able to maintain the continuity of the company in the long term. A company with good profitability indicates that the company has good prospects so that the survival and development of the company will be more secure. Profitability is the result of the policies and decisions taken by the company, in this case, management.

Profitability of banks is an important indicator that is seen by investors, in which the profitability of companies is one indicator to assess the financial performance of the company. Profitability is the most appropriate indicator for measuring the performance of the bank (Sofyan, 2013). Bank Indonesia prefer the value of a bank's profitability as measured by the value of the assets which funds mostly come from third party funds (DPK). ROA is used to measure the efficiency and effectiveness of the company in generating profits by exploiting its assets. The high ROA indicates that banks are getting better at using its assets. A company with a high level of profitability shows that the company can utilize its assets to obtain greater profits. 
Sugeng Haryanto / Profitability Identification of National...

This study will further examine the variables that influence the income of the bank. The influencing variable is variable that is identical to the criteria of the banking system, especially in Indonesia. The next part of this paper is Hypothesis Development in section 2, which will spell out the logic behind the test in this study. The next section will discuss the research method in this study followed by Results and Discussion then Conclusions and Recommendations.

\section{Hypothesis Development}

Bank acts as an intermediary institution, with lending as the primary activity of it. To shore up credit, source of the fund from the public is a mainstay of a bank. Credit is the bank's main source of income, such as interest rate spread of deposits and loans charged by bank. Therefore, the higher the DPK, the bank has the potential ability to be able to distribute in the form of loans, which in turn will be able to increase profits and profitability of a bank. Banks with large DPK will try to channel in the form of credit maximally by sticking to the principle of prudence.

The intermediation function of banks will be able to run well when a bank with large DPK can deliver in the form of credit. According to Meidianawathi (2007) in reality the bidding behavior of bank credit is not only influenced by the available funds sourced from DPK, but also influenced by the perception of banks on the prospects of the debtor's business and the banking system itself such as capital or CAR (Capital Adequacy Ratio), the amount of jammed credit or NPL.

Credit is the dominant source of bank revenue that would affect the profitability of bank. Because of the highest revenue is reached from interest rate. The allocation of substantial fund for lending requires significant financing, since otherwise, it would disturb the bank's liquidity. Each credit expansion plan should be supported by additional capital, because if not then the credit expansion will impact on decreasing the bank's CAR.

$\mathrm{H} 1$ : Credit influences the profitability in the banking industry
The problem that should always be a priority of the bank is the problem of capital. The role of capital is very important in the banking industry because it can support the operational activities of the bank to run smoothly (Sari, 2013). The size of bank capital which is often used CAR, which is the capital ratio that indicates the ability of banks to provide a fund for the purpose of business development and accommodating the risk of loss of fund caused by the operational activities of the Bank (Ali, 2006). This CAR ratio is a ratio that takes into account how far the entire assets of the bank which contain risks involved to be financed by owner capital, fund from sources outside the bank, such as the public, borrowing (debt) and so on.

CAR demonstrates the ability of bank financial resources which can be used for business development purposes and to anticipate potential losses from the credit channeled. The bigger the bank's capital adequacy ratio indicates that the bank is more solvable. Banks with high CAR will increasingly bear the risk of any credit or productive assets that are at risk and able to finance the bank's operations. Large CAR ratio indicates large bank capital, so that the Bank will have the discretion to place the fund from the capital to the productive asset portfolio, so it will contribute positively to the profitability of the bank.

Research shows various results. Aini (2013) CAR effects on profit change. Sangmi and Nazir (2010), Sudiyatno and Suroso (2010) CAR effects on ROA. Results of research conducted by Hutagalung and Ratnawati (2013), Eng (2013), Natalina et al. (2012), Akhtar and Sadaqat (2011), Sudiyatno and Fatmawati (2013) showed that the CAR does not affect the ROA.

$\mathrm{H} 2$ : CAR influences the profitability in the banking industry

One important thing faced by fund managers is how to determine the capital structure. Capital structure decisions will be linked to the company's operation continuation (Fatrisia \& Rahardja, 2015). The use of debt is a strategic 
decision since it takes a long-term financial consequence which effects on the risk and the firm value. The structure of debt capital and own capital is known as capital structure. Each company will establish the proportion of debt (capital structure) by the needs and financial conditions faced.

The company will try to achieve an optimal capital structure. The capital structure is the optimal capital structure which optimizes the balance between risk and return (Haryanto, 2014). The optimal capital structure of a company is a combination of debt and equity that can improve the profitability and high value of the company. Myers (1977) in Balancing theory explains that the proportion of debt usage can increase the value of the company at a certain level, but after passing the optimal limit the use of debt can lower the value of the company.

The company will try to do the optimal capital structure policy. Company Chen (2005) conducted a test related to the optimal capital structure with investment opportunities. The results stated that the optimal capital structure is not static, but is determined by the availability of investment opportunities, opening up investment opportunities can shift the optimal capital structure. The concept of capital structure emphasizes the company's prospects in the future.

H3: DER influences the profitability in the banking industry

The company's ability to determine the optimal capital structure will determine the profitability of the company. It is not independent of the risk that must be borne by the company and also return to be received by the company from the use of sources of funding that has been done. With the optimal capital structure, the company will be able to make debt as leverage or a lever, so the company will be able to improve its profitability.

Results of research linkages between capital structures to profitability showed different results. Agiomirgianakis and Magoutas (2012), as well as Wahyu (2012), showed that the capi- tal structure influenced profitability. The research findings of Fachrudin (2011), Wibowo and Wartini (2012) capital structure does not affect the profitability. The findings of $\operatorname{Lin}$ (2006) ratio of debt to assets negatively affects the company's performance.

Efficiency is a very important determinant of the activities of a company. Efficiency in the banking industry as a whole is an important aspect to be considered in efforts to achieve a bank performance that is healthy and sustainable (Abidin \& Endri, 2009). Under conditions of tight competition these days, banks are required to afford efficient in its operations. Banks that are not efficient will likely not be able to compete with its competitors, both in the pricing and quality of products and services, so that the bank will probably exit from the market. Wheelock and Wilson (1999) efficiency is an important measure of operating conditions of the bank and is one of the key indicators of success of a bank.

The efficiency of banks can be proxied by the BOPO. BOPO is the ratio between operating expenses to operating income. BOPO will be measured by whether the bank's management has been using all the factors of production effectively and efficiently. The greater BOPO shows, the greater amount of operating costs, so it will likely decrease the profitability of banks.

Results of research conducted by Subandi and Ghozali (2013), Aini (2013), Hutagalung and Ratnawati (2013), Sudiyatno and Fatmawati (2013), Sudiyatno and Suroso (2010), Yuliani (2007), Mawardi (2005) showed efficiency negatively effects the ROA. Research conducted by Zamil \& Rahman (2007) showed that BOPO positively affects ROA. Eng (2013) study showed BOPO had no effect on ROA.

$\mathrm{H} 4$ : Efficiency influences the profitability in the banking industry

The ability of bank management to manage problematic loans can be seen from the value of Non-Performance Loan (NPL). NPL is a ratio that reflects the credit risk, where the higher NPL a bank, then the greater the credit risk borne by banks. The higher NPL bank indi- 
Sugeng Haryanto / Profitability Identification of National...

cates, the worse the credit quality and vice versa. The higher NPL will increase the cost, both the provision charge of productive assets and other costs. Conversely, the smaller NP will decrease the cost. The higher NPL indicates a bank's credit problems are rising, so the effect on earnings decline. So the greater the NPL would interfere the performance of a bank (Hutagalung et al., 2013).

Saryadi (2013) research results, Qin and Pastori (2012), Harmanta and Ekananda (2005) showed that the risk had negative influence on bank credit. Research of Hutagalung and Ratnawati (2013), Eng (2013) shows that the NPL affects the ROA as well as the NPL negatively affects profit change. Research of Roring (2013) NPL has no effect on lending. Negara and Sujana (2014), Suhardi and Altin (2013) NPL does not affect the ROA. Muliawati and Khoiruddin (2015) which examines the determinants of profitability in Islamic banks shows FDR has no effect on profitability.

H5: Risk influences profitability in the banking industry

Based on these arguments, it can be arranged into a framework that will guide this research.

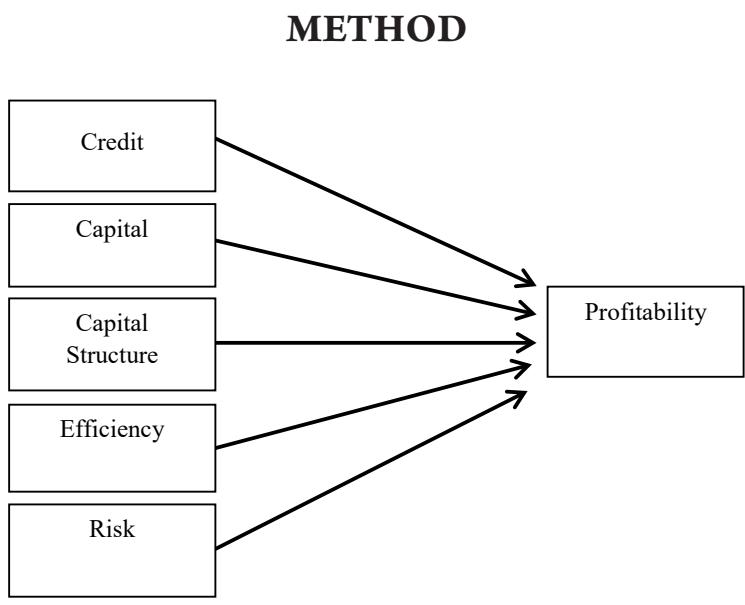

Figure 1. Framework

The sampling technique used in this research is purposive sampling, with the criteria of banks that go public before 2008 and the commercial banks to publish financial statements from 2008 until 2013. The number of samples in this study was 25 banks. The dependent variable used profitability variable which is measured by ROA, and calculated with the following formula.

$$
R O A=\frac{\text { Earning After Tax }}{\text { Total Assets }}
$$

Independent variables used are credit $\left(\mathrm{X}_{1}\right)$. The purpose of bank lending is to earn interest income, in which the higher the credit channeled, the interest income tends to be greater with the notes that the bank should stick to the principle of prudential banking. Variable $\mathrm{X}_{2}$ is bank capital proxied by capital adequacy ratio (CAR).

$$
C A R=\frac{\text { Owner's Capital }^{\prime}}{A T M R}
$$

The structure of bank capital is proxied by debt to equity ratio (DER) (X). DER is the ratio between the amount of debt with the size of the equity of the company. The higher the DER showed that, the higher the company's liabilities compared with equity.

$$
D E R=\frac{\text { Debt }}{\text { Equity }}
$$

Measurement of bank efficiency is proxied by comparing the Operating Costs with Operating Income ( $\mathrm{ROA})\left(\mathrm{X}_{4}\right)$. BOPO higher indicates banks are increasingly inefficient and vice versa.

$$
B O P O=\frac{\text { Operating Costs }}{\text { Operating Income }}
$$

The bank's risk in this study is proxied by the amount of non-performing loans (NPL) $\left(\mathrm{X}_{5}\right) . \mathrm{NPL}$ is the ratio of nonperforming loans to total outstanding loans.

$$
N P L=\frac{\text { Nonperforming Loans }}{\text { Total Loans }}
$$


Systematically, the model developed to analyze the effect of variable credit; CAR, Capital Structure, Efficiency and Risk to the profitability of banks used multiple regression model. To eliminate the variables of different sizes, then the regression model formulated as follows:

$$
\begin{aligned}
\mathrm{ROA}_{\mathrm{i}, \mathrm{t}}= & \beta_{1} \mathrm{Credit}_{\mathrm{i}, \mathrm{t}}+\beta_{2} \mathrm{CAR}_{\mathrm{i}, \mathrm{t}}+\beta_{3} \mathrm{DER}_{\mathrm{i}, \mathrm{t}} \\
& +\beta_{4} \mathrm{BOPO}_{\mathrm{i}, \mathrm{t}}+\beta_{5} \mathrm{NPL}_{\mathrm{i}, \mathrm{t}}+e
\end{aligned}
$$

Explanation:

Y: Profitability (ROA)

$\mathrm{b}_{1-5}:$ Regression coefficients

Credit: Total loans disbursed

CAR: Capital adequacy ratio

DER: Capital Structure

BOPO: The efficiency of the bank's performance

NPL: The risk of bad debts

\section{RESULT AND DISCUSSION}

Bank is an industry with a high level of regulation (highly regulated) as stipulated by Bank Indonesia. As an intermediary institution, bank funding sources are dominated by public funds, which then make the bank should be arranged so that depositors will be protected. Bank is an institution known as the risk-taking entities. Bank is an institution in which its operations are associated with risks in comparison with the manufacturing company and other companies.

The average profitability of the national banking system in 2008-2013 showed well, with their mean for BUSN 1.18. The major banks showed a good performance, as shown by a high enough ROA. Bank BCA average ROA of 2.99, and Bank Danamon and Bank BTPN in the same period each posted a ROA of 2.74 and 2.99. Bank Pundi Indonesia (BEKS) in 2010 was recorded ROA of -10.66 as a result of BEKS in 2010 that suffered losses. In the year 2008-2012 BEKS continued suffering losses, and then in 2013 it posted the profit. Bank CIC in 2013 suffered a great loss, in which the operating costs were far above the operating income (BOPO reached 1.8), so the ROA was -7.79 .
The average loan which is the bank's main source of income during the period 2008-2013 disbursed by the bank industry amount IDR 30.7 trillion. Three banks that carry most credits was in 2013; BRI, amounting to IDR 434.3 T, Bank Mandiri IDR 409.9 T and Bank BCA amounted to IDR 306.2 T. Average capital of BUSN was still above the standard 8 percent, where the average CAR of 16.39. The capital structure of the banks over the years 2008-2013 reached the average by 8.59 percent. Bank Pundi Indonesia has the greatest capital structure, i.e., of 15.92. The average bank BOPO of 81.8 percent. BOPO of national banks are still high, but still below the Bank Indonesia regulation. Benchmark BOPO for general bank business groups (BUKU) I up to 85 percent. Non-performing loans or NPL average is still below the Bank Indonesia provisions, which are still below the 3.05 percent (still below the $\mathrm{BI}$ requirements of 5 percent).

Normality test of data was done by using normal plot diagram. The test results indicate the data were not normally distributed, and based on the homogeneity test showed a scatter plot between the predicted standardized value (ZPRED) with standardized residual value (SRESID) form a pattern, which clumps together. To re-testing was done by the natural logarithm of the variables of the study, so the amount of data is reduced to 141 from 150 pairs of data. Based on the results of normality test of data with the data that has been logarithm showed that the data have normal distribution.

Homogeneity test was done by using the scatter plot between standardized predicted value (ZPRED) with standardized residual value (SRESID). The test results showed that the data were homogeny, it is indicated by the distribution or plots in the scatter plot shows the spread and does not form a specific pattern or spread above and below zero on the axis standardized residual or $Y$ axis on the right and left of the axis of standardized predicted value.

The autocorrelation test was done by using DW. The analysis shows DW values for 1.073 (Table 1), with the amount of data (n) 
Sugeng Haryanto / Profitability Identification of National...

of 141 and a table Durbin-Watson with a 0.05 earned value dU by 1.7988 and $\mathrm{dL}$ by 1.6522 . DW count value was between dU (1.7206) and 4-dU (2.2012) so that it can be concluded that there was no autocorrelation. Multicollinearity test by using Varian Inflation Factor (VIF) value indicates the VIF value (Table 1 ) is smaller than 10 , so it cannot happen any multicollinearity.

Based on the goodness fit of the model test by looking at Table 1 , it shows that simultaneously variable credit, capital, capital structure, efficiency and risk effect on profitability (ROA) in the banking industry. This indicated by the $\mathrm{F}$ probability value of 0.000 , in which this value is less than 0.05 . The partial test shows that the hypothesis test for hypotheses one up to 5, they are the effect of variable Credit, Capital, Capital Structure, Efficiency and Risk toward Profitability shows that each variable influences significantly. This is demonstrated with a probability value of each variable is less than 0.05 . Variable Credit, Capital and Capital Structure influence with a positive direction, while for the variable efficiency (BOPO) and Bank Risk (NPL) influence with negative direction.

\section{The Influence of Credit towards the Profita- bility (ROA)}

Partial test results indicate that the credit affects profitability in a positive direction. This indicates that credit enhancement will tend to increase the income of the bank, with a record of not increasing the cost of funds, which will further increase the profitability of banks. The greater credit can be distributed; then the interest income will likely increase. Until now, interest income from loans is the dominant source of bank revenue, compared to non-interest income. This shows that banks still rely on revenues from traditional activities, i.e., lending. The income from this activity tends to fluctuate, as it would be greatly influenced by the price of the fund and also the condition of the real sector. Spread bank interest, namely the difference between lending with savings interest is the profit earned from the bank from intermediary function performed.

Bank income is derived from interest income and non-interest income (fee base income). Effect of significant credit shows that bank still relies on revenues from lending. Revenue from services of the bank has not made a great contribution. Most banks in Indonesia, especially domestic banks are not maximizing revenue from fee base income (Subandi \& Ghozali, 2013).

ROA-year growth in the last few years experienced a decline. It shows the performance of banks has decreased, it is influenced by slowing credit growth, credit risk began to rise, and interest rates increased funding. The decline in credit growth is strongly influenced by the growth of the real sector. When the real sector

Table 1. Hypothesis Testing

\begin{tabular}{|c|c|c|c|c|c|}
\hline Variable & $\begin{array}{c}\text { Standardized } \\
\text { Coefficients Beta }\end{array}$ & $\mathbf{t}$ & Sig. & VIF & Explanation \\
\hline Credit & .183 & 2.547 & .012 & 1.123 & Significant \\
\hline Capital & .162 & 2.039 & .043 & 1.368 & Significant \\
\hline Capital Structure & .311 & 4.393 & .000 & 1.084 & Significant \\
\hline Efficiency & -.355 & -4.851 & .000 & 1.164 & Significant \\
\hline Bank Risk & -.171 & -2.160 & .032 & 1.364 & Significant \\
\hline$\overline{\mathrm{DW}}$ & $: 1.073$ & & & & \\
\hline $\mathrm{R}^{2}$ & $: 0.336$ & & & & \\
\hline $\mathrm{R}_{\text {Adjusted }}^{2}$ & 0.330 & & & & \\
\hline $\mathrm{F}_{\text {Count }}$ & $: 14.581$ & & & & \\
\hline Sig F & $: 0.000$ & & & & \\
\hline
\end{tabular}


experienced a decline, it will have an impact on the uptake of credit by the real sector.

\section{The Influence of Capital (CAR) towards the Profitability (ROA)}

The results showed that CAR had positive and significant impact on profitability. CAR for banks serves to accommodate the risk of loss that may be faced by the bank. The higher the CAR means, the better the ability of the bank to perform expansion besides its effort to cover the risk of each loan / assets at risk. If the CAR value is higher, then the bank will be able to finance its operations and contribute significantly to profitability. High bank CAR, when the bank requires the allocation of substantial funds financing for credit will be able to discover the capital, so as not to disturb the bank's liquidity.

The average CAR of the national banking industry is quite well, which is above 8 percent. When the capital adequacy ratio is high, the bank will be able to finance its operations and provide a considerable contribution to profitability. Conversely, when the CAR is low, then the bank will be difficult to finance its operations and cover the risks. CAR of a bank is not static, but dynamic. The higher the capital invested in the bank, the higher the profitability of banks.

The results of this study support the research conducted by Sangmi and Nazir (2010), Sudiyatno and Suroso (2010) CAR affects ROA. However, the research does not support Hutagalung and Ratnawati (2013), Eng (2013), Natalina et al. (2012), Akhtar and Sadaqat (2011), Sudiyatno and Fatmawati (2013) in which the results showed CAR had no effect on ROA.

\section{The Influence of Capital Structure towards the Profitability (ROA)}

The results indicate that the capital structure influences profitability with a positive direction. This shows that the larger the capital structure will tend to increase the profitability of the company. The large capital structure of the company shows high bank debt. The high bank debt is due to high DPK. High DPK cannot be separated from the function of a bank as an intermediary institution, in which one of its activities is to collect public funds in the form of savings deposits, time deposits and demand deposits.

High capital structure of a bank shows that large DPK is collected by the bank, in which with large DPK, the bank has a source of funds to extend credit. Sources of funds for commercial banks are still dominated by third-party funds which reached 91\% (Bank Indonesia: 2014).

The results of this study support the research of Hill (2012), Agiomirgianakis and Magoutas (2012), and Wahyuni (2012) that showed that the capital structure affected with a positive direction towards profitability. Findings of Lin (2006) show that ratio of debt to assets negatively affects the company's performance. The results of this study do not support the research by Fachrudin (2011), Wibowo and Wartini (2012) where the capital structure does not affect the profitability.

\section{The Influence of Efficiency (BOPO) towards the Profitability (ROA)}

The analysis results of efficiency (BOPO) to profitability indicate that the $\mathrm{BOPO}$ affects profitability with negative direction. This means that the higher the BOPO (lower efficiency), the profitability tends to be higher and vice versa. Bank efficiency is one measure that can be used to see the performance of the bank. The more efficient a bank then the performance will also be getting better. The greater BOPO means, the greater amount of operating costs, so it will likely decrease the profitability of banks. The average BOPO of national banking is still high, which BOPO in 2013 and 2014 respectively by $80,85.3,74.1$ and 76.9 while ROA in 2014 has decreased compared to 2013. The high BOPO heavily influenced by the high cost of funds, where banks still rely on revenues from traditional activities, i.e., lending. Therefore, when the cost of funds rises, it will greatly affect the level of efficiency of the bank.

The results of this study support the research done by Subandi and Ghozali (2013), 
Sugeng Haryanto / Profitability Identification of National...

Aini (2013), Hutagalung and Ratnawati (2013), Sudiyatno and Fatmawati (2013), Sudiyatno and Suroso (2010), Yuliani (2007), Mawardi (2005) that showed efficiency has negative effect on ROA. However, it does not support the research by Zamil and Rahman (2007) which showed that BOPO has positive effect on ROA and Eng (2013) which showed there is no effect of BOPO on ROA.

\section{The Influence of Risk (NPL) towards the Profitability (ROA)}

NPL is a financial ratio that can be used to measure the credit risk; this ratio measures the ability of banks to minimize credit problems faced. The results showed that the NPL affects profitability in a negative direction. This means that the lower the NPL, profitability will tend to rise and vice versa. High NPL indicates that the management of the bank credit is not optimal resulting credit risk faced by the bank would be high. Banks with high NPL indicate that there is high nonperforming loan. Therefore, the bank will form a reserve of productive assets expense in the form of PPAP (allowance for uncollectible) and CKPN (impairment losses).

The results of this study support the research done by Saryadi (2013), George et al., (2013), Hutagalung and Ratnawati (2013), Qin and Pastory (2012) as well as the Han and Ji-Yong (2012), Jha and Xio (2012) and Chang (2006) that found the results that NPL significantly influences profitability with negative direction. However, this study does not support the research of Muliawati and Khoiruddin (2015), Negara and Sujana (2014), Suhardi and Altin (2013), Nawaz (2012), Kutubi (2011) that NPL does not affect the ROA.

\section{CONCLUSION AND RECOMMENDATION}

Bank holds an important role in the economy, which is reflected in the ratio of credit to GDP in Indonesia in 2014 at around 36 percent (Bank Indonesia, 2014). Banking has an 80 percent market share in the financing (credit) of the intermediation function of the entire existing financial system (Astohar, 2009). The function of financial intermediary arises as a result of the high cost of monitoring, the cost of liquidity and price risk since there is information asymmetric between the owner of the funds (household) with the user funds company (corporations / net borrowers), and so we need an intermediary which can accommodate the needs of both parties (Saunders and Cornett, 2008).

The influence of causality between credit, capital (CAR), capital structure (DER), efficiency (BOPO) and the risk to profitability (ROA) in the banking industry. By using a multiple regression analysis of credit, bank capital and capital structure affect the profitability with a positive direction. This shows that the national banks are still reliant on income from traditional activities, i.e., of loan interest income. Variable efficiency and risk have significant effect on profitability in a negative direction. The amount of credit, capital (CAR) and the capital structure of the dominant form of DPK debt are all factors that sustain traditional activities. Likewise, the efficiency and the risk are the backbones of traditional activities related to credit management.

This study was limited to objects BUSN with the study period of 2008-2013. Further research can be done with larger objects. Variables to identify profitability can be done with the efficiency variable that can be used with cost frontier analysis approach and other variables.

\section{REFERENCES}

Abidin, Z \& Endri, 2009. Kinerja Efisiensi Teknis Bank Pembangunan Daerah: Pendekatan Data Envelopment Analysis (DEA). Jurnal Akuntansi dan Keuangan. 11 (1):21-29.

Agiomirgianakis, M. G \& Magoutas, I. A. 2012. Determinants of profitability and the decision-making process of firms in the tourism sector: the case of Greece. Int. J. Decision Sciences, Risk and Management. 4 (3-4): 294-299.

Aini, N. 2013. Pengaruh CAR, NIM, LDR, NPL, BOPO dan Kualitas Aktiva Produktif Terhadap Perubahan Laba. Jurnal Dinamika Akuntansi, Keuangan dan Perbankan. 2 (1): 14 - 25. Akhtar, A \& Sadaqat. 2011. Factor Influencing the 
Profitability Conventional Banks of Pakistan. International Research Journal of Finance and Economic. 66.

Ali, M. 2006. Manajemen Resiko: Strategi Perbankan dan Dunia Usaha Menghadapi Tantangan Globablisasi Bisnis. Jakarta: PT Raja Grafindo Persada.

Astohar. 2009. Analisis Faktor yang Mempengaruhi Profitabilitas Perbankan Di Indonesia (Studi Pada Bank Domestik, Bank Campuran dan Bank Asing). Universitas Diponegoro Semarang.

Chang, Y. T. 2006. Role of Non-Performing Loans (NPLs) and Capital Adequacy in Banking Structure and Competition. Economic \& Social Research Council, Center for Competition Policy. ISSN 1745-9648, CCP Working Paper 06-15.

Chen, L. 2005. Profitability, Mean Reversion of Leverage Ratios and Capital Structure Choices. Michigan State University and Kent State University.

Eng, T. S. 2013. The Effect of NIM, Operational Efficiency Ratio (BOPO), LDR, NPL \& CAR Toward ROA of International And National Public Listed Banks For The Period of 20072011. Journal of Dinamic Management, 153167.

Fachrudin, K. A. 2011. Analisis Pengaruh Struktur Modal, Ukuran Perusahaan dan Agency Cost Terhadap Kinerja Perusahaan. Jurnal Akuntansi dan Keuangan. 13 (1): 37-46.

Fatrisia, A \& Rahardja, E. 2015. The Influences of Company Characteristic, Entrepreneurship Behaviour and Bank Relationship toward Small and Medium Enterprises (SMEs) Performance. Jurnal Dinamika Manajemen. 6 (1): 1-12.

George, G. E., Barrack, O. O \& Jane, N. W. 2013. Effect Of Financial Risk On Profitability Of Sugar Firm In Kenya. European Journal of Business and Management. 5 (3).

Han, X \& Ji-Yong S. 2012. Influential Factors In Lending And Profitability In Commercial Chinese Banks. African Journal of Business Management. 6(36): 10041-10049.

Harmanta \& Ekananda, M. 2005. Disinterminasi Fungsi Perbankan di Indonesia Pasca Krisis 1997: Faktor Permintaan dan Penwaran Kredit, Sebuah Pendekatan dengan Model Disequilibrium. Buletin Ekonomi Moneter dan Perbankan.
Haryanto, S. 2014. Identifikasi Ekspektasi Investor Melalui Kebijakan Struktur Modal, Profitabilitas, Ukuran Perusahaan dan CGPI. Jurnal Dinamika Manajemen. 5 (2): 183-199.

Hutagalung, N. E. D \& Ratnawati, K. 2013. Analisa Rasio Keuangan terhadap Kinerja Bank Umum di Indonesia. Jurnal Aplikasi Manajemen. 11 (1).

Jha, S \& Xiao, F. H. 2012. A Comparison of Financial Performance of Commercial Banks: A Case Study of Nepal. African Journal of Business Management. 6 (25): 7601.

Kutubi, S. S. 2011. Board of Director's Size, Independence and Performance: An Analysis of Private Commercial Banks in Bangladesh. World Journal of Social Sciences. 1 (4): 159-178.

Lin, K. 2006. Study on Related Party Transaction With Mainland China in Taiwan Enterprises. University Guo Cheng Gong China.

Mawardi, W. 2005. Analisis Faktor-Faktor yang Mempengaruhi Kinerja Keuangan Bank Umum di Indonesia. Jurnal Bisnis Strategi. 14 (1).

Meidianawathi, L. G. 2007. Analisis Perlaku Penawaran Krdit Perbankan Kepada Sektor UMKM Di Indonesia (2002-2006). Buletin Studi Ekonomi. 12 (2).

Muliawati, S \& Khoiruddin, M. 2015. Faktor-faktor Penentu Profitabilitas Bank Syariah Di Indonesia. Management Analysis Journal. 4 (1): 3949.

Myers, S.C. 1977. Determinants of Corporate Borrowing. Journal of Financial Economics. 5.

Natalina, A., Pratiwi, W \& Nariya, A. 2012. Analisis Capital Adequacy Ratio (CAR) dan Aktiva Tetap Terhadap Modal (ATTM) terhadap Profitabilitas Pada PT Bank Permata, Tbk. UG Jurnal. 6 (12).

Nawaz, M. 2012. Credit Risk and The Performance of Nigerian Banks. Interdisciplinary Journal of Contemporary Research in Business. 4 (7).

Negara, I. P. A. A \& Sujana, I. K. 2014. Pengaruh Capital Adequacy Ratio, Penyaluran Kredit dan Non Performance Loan. E-Jurnal Akuntansi Universitas Udayana. 9 (2): 325-339.

Qin, X \& Pastory, D. 2012. Commercial Banks Profitability Position: The Case of Tanzania. International Journal of Business and Management. 7 (13): 136.

Roring, D. J. G. 2013. Analisis Determinan Penyaluran Kredit oleh Bank Perkreditan Rakyat (BPR) di Kota Manado. Jurnal EMBA. 1 (3). 
Sugeng Haryanto / Profitability Identification of National...

Sangmi, M. D \& Nazir, T. 2010. Analyzing Financing Performance of Commercial Bank in India: Application of CAMEL Model. Journal Pak. J. Commer. Soc.Sci. 4 (1).

Sari, Y. 2013. Pengaruh Profitabilitas, Kecukupan Modal dan Likuiditas Terhadap Harga Saham (Perusahaan Perbankan yang Terdaftar di BEI). Jurnal Akuntansi. 1 (1).

Saryadi. 2013. Faktor-Faktor yang Berpengaruh Terhadap Penyaluran kredit Perbankan (Studi pada Bank Umum Swasta Nasional Devisa). Jurnal Administrasi Bisnis. 2 (1).

Saunders, A \& Cornett, M. M. 2008. Financial Institutions Management: A Risk Management Approach. Sixth Edition. Mc Graw Hill International Edition. New York

Sofyan, S. 2013. Keputusan Go Public dan Hubungannya dengan Bank-Bank Swasta di Indonesia. Jurnal Media Riset \& Manajemen. 3 (1).

Subandi \& Ghozali, I. 2013. Determinan Efisiensi dan Dampaknya Terhadap Kinerja Profitabilitas Industri Perbankan Di Indonesia. Jurnal Keuangan dan Perbankan. 17 (1).

Sudiyatno, B \& Suroso, J. 2010. Analisis Pengaruh Dana Pihak Ketiga, BOPO, CAR dan LDR Terhadap Kinerja Keuangan Pada Sektor Perbankan Yang Go Public Di Bursa Efek Indonesia (BEI) Periode 2005-2008. Dinamika Keuangan dan Perbankan. 2 (2).

Sudiyatno, B \& Fatmawati, A. 2013. Pengaruh Resiko Kredit dan Efisiensi Operasional Terhadap Kinerja Bank (Studi Empirik Pada Bank yang Terdaftar di Bursa Efek Indonesia). Jurnal Organisasi dan Manajemen. 9 (1): 73-86.

Suhardi \& Altin, D. 2013. Analisis Kinerja Keuangan Bank BPR Konvensional di Indonesia Periode 2009-2012. Pekbis Jurnal. 5 (2): 101-110.

Sudjoko \& Soebiantoro, U. 2007. Pengaruh Struktur
Kepemilikan Saham Leverage Faktor Intern dan Faktor Ekstern Terhadap Nilai Perusahaan. Jurnal Manajemen dan Kewirausahaan. 9 (1): 41-48.

Wahyuni, S. 2012. Efek Struktur Modal Terhadap Profitabilitas Pada Perusahaan Manufaktur Yang Terdaftar Di Bursa Efek Indonesia. Management Analysis Journal. 1 (2)

Wheelock, D. C \& Wilson, P. 1999. Technical Progress Inefdiciency and Productivity Change in U.S. Banking 1984-1993. Journal of Money, Credit and Banking. 31.

Wibowo, Agus dan Wartini, Sri. 2012. Efesiensi Modal kerja, Likuiditas dan Leverage Terhadap Profitabilitas Pada Perusahaan Manufaktur di BEI. Jurnal Dinamika Manajemen (Journal of Management Dynamics), 3 (1): 49-58

Lin, K., 2006. Study on Related Party Transaction With Mainland China in Taiwan Enterprises. University Guo Cheng Gong China.

Yuliani. 2007. Hubungan Efisiensi Operasional dengan Kinerja profitabilitas Pada Sektor Perbankan yang Go Publik Di Bursa Efek Jakarta. Jurnal Manajemen \& Bisnis. 5 (10).

Zamil, N. A. M \& Rahman, A. R. A. 2007. Efficiency of Islamic and Conventional Bank in Malaysia: A Data Envelopment Analysis (DEA) Study. Paper Presented at the IIUM International Conference on Islamic Banking and Finance (IICiBF): Research and Development: The Bridges between Ideals and Realities. IIUM Kuala Lumpur.

Bank Indonesia. 2012. Laporan Perekonomian Indonesia. 2012.

Indonesia. 2013 2013. Laporan Perekonomian 2014. Laporan Perekonomian Indonesia. 2014 